\title{
Trends in penaeid shrimp landings by sona boats at Visakhapatnam Fishing Harbour, Andhra Pradesh
}

\author{
G. MAHESWARUDU*, MIRIAM PAUL SREERAM, E. DHANWANTHARI, J. B. VARMA, \\ C. K. SAJEEV, S. SATYA RAO AND K. NARAYANA RAO \\ ICAR-Central Marine Fisheries Research Institute, Visakhapatnam Regional Centre, Pandurangapuram \\ Visakhapatnam - 530 003, Andhra Pradesh, India \\ e-mail:maheswarudu@yahoo.com
}

\begin{abstract}
Sona boats operate mostly in the northern part of the Bay of Bengal up to sand heads. The boats (13-15 m OAL) worthy to conduct voyage fishing for 10-20 days exploit resources upto a depth of $100 \mathrm{~m}$. The present study analysed the trends in penaeid shrimp landings by sona boats at Visakhapatnam Fishing Harbour, for the period from 2001 to 2010. During the period, annual fishing effort ranged from 4,77,710 to 16,31,507 $\mathrm{h}$ with an average of 10,15, $230 \mathrm{~h}$. Annual penaeid shrimp catch varied from 1,409 to 7,496 t, average being 4,892 t. Average catch per hour $(\mathrm{CPH})$ was estimated at $4.81 \mathrm{~kg}$. Annual penaeid shrimp contribution from the sona boats to the total fish landings was 10.2 to $22 \%$ (average 15.9). Both fishing effort and penaeid shrimp catch showed increasing trend during the period. Penaeid shrimp fishery was supported by 14 genera/species dominated by Metapenaeus monoceros followed by M. dobsoni. Mean annual species composition and CPH for each species were computed for two span, first being 2001-2005 and the second during 2006-2010. The CPH for the penaeid shrimps increased by $1.5 \%$ from span- 1 to span-2. CPH for smaller shrimp species declined whereas increased for commercial species. Expected catch for each year estimated by Schaefer production model (CEDA; $\left.\mathrm{r}^{2}=0.72\right)$ showed underexploitation during 2001 and 2004; optimum state of exploitation for four years during 2005, 2006, 2007 and 2009 and overexploitation for four years during 2002, 2003, 2008 and 2010. In terms of total fish landings, 2001 and 2002 showed underexploitation, optimum state during six years i.e., 2003, 2006, 2007, 2008, 2009 and 2010; while overexploitation during 2004 and 2005. Considering the exploitation rate of both penaeid shrimps and total fish, by sona boats, the study suggests restriction of fishing effort at the 2009-2010 level to ensure sustainability of the resources.
\end{abstract}

Keywords: Bay of Bengal, Catch and effort, Penaeid shrimp catch, Schaefer production model, Sona boats, Total fish landings, Visakhapatnam

\section{Introduction}

Exploratory bottom trawling operations by the Fishery Survey of India (FSI) during the 1960s along the north-east coast of India, off West Bengal, Odisha and Andhra Pradesh (Naumov, 1961; Poliakov, 1961, 1962; Borisov, 1962) under the Indo-Norwegian project led to the introduction of small mechanised trawlers for exploitation of shrimps in the Bay of Bengal. Small mechanised trawlers initially in 1964 were Pablo type (9.14 m length; $2.14 \mathrm{~m}$ beam; and 40-45 HP engine) and within three years, other two types, namely Royya (9.75 -10.0 m length; $2.9 \mathrm{~m}$ beam; and 45-60 HP engine) and Sorrah (11.4 m length; $3.2 \mathrm{~m}$ beam; and 60-80 HP engine) with modifications in structure and engine capacity were introduced. They were effectively used for single day to short term cruise of 2-3 days until 1987 for exploitation of shrimps in the coastal waters (Chittibabu et al., 1988; Maheswarudu et al., 2015). Sona boats were introduced in 1987 along the Andhra coast with an objective to conduct voyage fishing for a period of more than 10 days, to save fuel cost incurring on single day fishing. As the boats started landing large quantities of shrimps, resulting in increased earnings, the operators used the term "sona boats" $($ sona $=$ gold $)($ Rao, 1999) .

Sona boats (13-15 m OAL) based at Visakhapatnam Fishing Harbour, which are worthy of undertaking voyage fishing for 10-20 days, exploit resources up to a depth of $100 \mathrm{~m}$, mostly in the northern part of Bay Bengal up to sand heads and occasionally up to Nellore in the south. Shrimp trawls with $20 \mathrm{~mm}$ cod end mesh size scrap the bottom with $5 \mathrm{~m}$ height mouth opening. The engine capacity used is $102 \mathrm{HP}$ and strength of crew in the boat is 9 . The sona boats are equipped with fish holding capacity of $5 \mathrm{t}$. Shrimp fishery by the sona boats at Visakhapatnam was reported earlier by Rao (1999) and Rajkumar et al. (2004). The present study is based on catch and effort as well as species composition data of penaeid shrimp landings by sona boats at Visakhapatnam Fishing Harbour, collected during 2001-2010. 


\section{Materials and methods}

Data on catch and effort, landings of penaeid shrimps, non-penaeid shrimps and total fish were collected as per the standard procedure adopted by Fishery Resources Assessment Division of ICAR-Central Marine Fisheries Research Institute (ICAR-CMFRI), Kochi (Kutty et al., 1973). The catches of observation days were raised to monthly catches by a factor based on observation days and total fishing days in the month. The number of fishing days, fishing hours, depth of operation and fishing grounds were recorded on enquiry from the crew. Weight of shrimps caught and dried in sona boats were converted in to wet weight by adding $70 \%$ of weight $(=70 \%$ water content).

Catch of penaeid shrimps, total fish and data on effort of sona boats for the period from 2001 to 2010 were analysed by catch effort data analysis (CEDA) following Schaefer production model (Kirkwood et al., 2001). The model was used to estimate expected catch of penaeid shrimps and total fish and also to determine the exploitation status of both the resources each year. Catch and effort data and species composition was split in to two spans, one for 2001-2005 and the other for 2006-2010 and compared to find out variation between the two spans.

\section{Results and discussion}

Annual fishing effort, landings of penaeid shrimps, non-penaeid shrimps and total fish by sona boats during 2001-2010 are presented in Table 1. Number of units operated per year ranged from 4,135 to 11,075 with mean at 7,575. Number of units operated per year increased by $35.8 \%$ from span-1 (2001-2005) to span-2 (2006-2010). Annual fishing effort increased from $4,77,710$ to $16,31,507 \mathrm{~h}$ with an average of $10,15,231 \mathrm{~h}$, recording increase by $37.5 \%$ from span-1 (2001-2005) to span-2 (2006-2010). Fishing effort per trip ranged from 115 to $166 \mathrm{~h}$, resulting in 7-9 actual fishing days per trip (excluding travelling period to approach fishing ground and journey back to fishing harbour). Generally six hauls per day (three during day hours and three during night), for $3 \mathrm{~h}$ each were performed by each boat. Fishing effort per trip did not vary much between two spans indicating that duration of voyage remained same throughout the decade and increase in fishing effort during span-2 was due to increase in number of cruise. The study by Rao (1999) on sona boat fishery, analysing four years data (1993-97) revealed that mean annual fishing effort in terms of units and hours were 5,418 and 5,10,957 respectively. Mean annual fishing effort $(7,575$ units and10,15,231 h) in the present study indicates that effort has been increased by 39.8 and $98.69 \%$ for units and hours respectively, during 2001-2010.

Annual catch of penaeid shrimps increased from 1,409 to $7,496 \mathrm{t}$ (average 4,601 t). The percentage increase was by $39.5 \%$ from span-1 $(3,842$ t) to span-2 $(5,360 \mathrm{t})$. Contribution of penaeid shrimps to total fish catch increased marginally by $4.5 \%$ from span-1 (15.5\%) to span-2 $(16.2 \%)$, the range being 0.2 to $22 \%$ with an

Table 1. Catch and effort of sona boats, based at Visakhapatnam Fishing Harbour during 2001-2010

\begin{tabular}{|c|c|c|c|c|c|c|c|c|c|c|c|}
\hline Year & $\begin{array}{l}\text { Effort } \\
\text { (units) }\end{array}$ & $\begin{array}{l}\text { Effort } \\
\text { (h) }\end{array}$ & $\begin{array}{l}\text { Effort/trip } \\
\text { (h) }\end{array}$ & $\begin{array}{l}\text { Penaeid } \\
\text { shrimp } \\
\text { catch } \\
\text { (t) }\end{array}$ & $\begin{array}{l}\text { Non- } \\
\text { penaeid } \\
\text { shrimp } \\
\text { catch } \\
\text { (t) }\end{array}$ & $\begin{array}{l}\text { Total } \\
\text { fish } \\
\text { catch } \\
\text { (t) }\end{array}$ & $\begin{array}{l}\text { CPH } \\
\text { of penaeid } \\
\text { shrimps } \\
(\mathrm{kg})\end{array}$ & $\begin{array}{l}\mathrm{CPH} \\
\text { of non-penaeid } \\
\text { shrimps } \\
(\mathrm{kg})\end{array}$ & $\begin{array}{l}\text { CPH } \\
\text { of total } \\
\text { fish } \\
(\mathrm{kg})\end{array}$ & $\begin{array}{l}\text { Contribution } \\
\text { of penaeid } \\
\text { shrimps to } \\
\text { total fish } \\
\text { catch }(\%)\end{array}$ & $\begin{array}{l}\text { Contribution } \\
\text { of non-penaeid } \\
\text { shrimps to } \\
\text { total fish catch } \\
(\%)\end{array}$ \\
\hline 2001 & 4135 & 477710 & 116 & 1409 & 0 & 11181 & 2.95 & 0.00 & 23.40 & 12.6 & 0.00 \\
\hline 2002 & 7040 & 1136976 & 162 & 5537 & 0 & 25125 & 4.87 & 0.00 & 22.10 & 22.0 & 0.00 \\
\hline 2003 & 8219 & 1131050 & 138 & 5851 & 0 & 32291 & 5.17 & 0.00 & 28.55 & 18.1 & 0.00 \\
\hline 2004 & 6697 & 769941 & 115 & 2861 & 0 & 28141 & 3.72 & 0.00 & 36.55 & 10.2 & 0.00 \\
\hline 2005 & 6039 & 759206 & 126 & 3551 & 0 & 26883 & 4.68 & 0.00 & 35.41 & 13.2 & 0.00 \\
\hline 2006 & 8273 & 1040440 & 126 & 4483 & 38 & 29832 & 4.31 & 0.04 & 28.67 & 15.0 & 0.13 \\
\hline 2007 & 6996 & 847170 & 121 & 3895 & 22 & 22901 & 4.60 & 0.03 & 27.03 & 17.0 & 0.09 \\
\hline 2008 & 8152 & 1108791 & 136 & 5634 & 18 & 30913 & 5.08 & 0.02 & 27.88 & 18.2 & 0.06 \\
\hline 2009 & 9124 & 1249518 & 137 & 5293 & 16 & 36179 & 4.24 & 0.01 & 28.95 & 14.6 & 0.04 \\
\hline 2010 & 11075 & 1631507 & 147 & 7496 & 77 & 45291 & 4.59 & 0.05 & 27.76 & 16.6 & 0.17 \\
\hline Mean & 7575 & 1015231 & 134 & 4601 & 17 & 28874 & 4.53 & 0.02 & 28.44 & 15.9 & 0.06 \\
\hline $\begin{array}{l}\text { Mean for } \\
2001-2005\end{array}$ & 6426 & 854977 & 133 & 3842 & 0 & 24724 & 4.49 & 0 & 28.92 & 15.5 & 0 \\
\hline $\begin{array}{l}\text { Mean for } \\
2006-2010\end{array}$ & 8724 & 1175485 & 135 & 5360 & 34 & 33023 & 4.56 & 0.03 & 28.09 & 16.2 & 0.10 \\
\hline$(+) /(-)$ by $(\%)$ & 35.8 & 37.5 & 1.3 & 39.5 & & 33.6 & 1.5 & & -2.9 & 4.5 & 0 \\
\hline
\end{tabular}


average of $15.9 \%$. Average annual catch per hour $(\mathrm{CPH})$ of penaeid shrimps was $4.53 \mathrm{~kg}$ (range 2.95 to $5.17 \mathrm{~kg}$ ), which showed an increase of only $1.5 \%$ from span-1 $(4.49 \mathrm{~kg})$ to span-2 $(4.56 \mathrm{~kg})$. The increase in catch from span-1 to span-2 may be attributed to increase in fishing effort by $37.5 \%$. Mean annual shrimp catch, $\mathrm{CPH}$ and contribution of shrimp to total fish catch from sona boats during 1993-97 was 1,147.25, $2.245 \mathrm{~kg}$ and 23.1\% respectively (Rao, 1999). Increase in mean annual shrimp catch (4,601 t) and CPH (4.53 kg) during the present study could be attributed to increase in exploitation. However, contribution of shrimps (15.9\%) to total fish catch in the present study was lower to that $(23.1 \%$ ) reported by Rao (1999).

Annual total fish catch ranged from 11,181 to $45,291 \mathrm{t}$ with an average of $28,874 \mathrm{t}$ which increased by $33.6 \%$ from span-1 $(24,724 \mathrm{t})$ to span-2 $(33,023 \mathrm{t})$. Annual $\mathrm{CPH}$ of total fish catch ranged from 22.1 to $28.55 \mathrm{~kg}$ with an average of $28.44 \mathrm{~kg}$. This has decreased marginally by $2.9 \%$ from span-1 $(28.92 \mathrm{~kg})$ to span-2 $(28.09 \mathrm{~kg})$. Increase in annual total fish catch from span-1 to span-2 was due to increase in fishing effort by $37.5 \%$. Rao (1999) reported mean annual total fish catch as $4964.6 \mathrm{t}$ with $\mathrm{CPH}$ of $9.71 \mathrm{~kg}$. The 5.8 fold increase in mean annual fish catch $(28,874 \mathrm{t})$ in the present study is due to increase in fishing effort (98.69\%) and CPH (192.8\%).

Contribution of non-penaeids annually to total fish catch was low $(0.06 \%)$. Their landings began in 2006 with the extension of fishing grounds to south of Visakhapatnam, off Godavari and Krishna estuaries which are potential grounds for non-penaeid shrimps due to the prevalence of low saline water preferred by them (Maheswarudu et al., 2015).

Trends in fishing effort, penaeid shrimp catch and total fish catch landed by sona boats during 2001-2010 are presented in Fig. 1. Overall, increasing trends were observed in fishing effort, penaeid shrimp and total fish catch of sona boats for the decade. Decrease in fishing effort during 2004 and 2005 that reflected on penaeid shrimp and total fish catch was due to the effect of tsumami-2004 and other cyclonic storms which restricted fishing operations of sona boats. Increase of fishing effort by $37.5 \%$ from span-1 to span-2, resulted in increase in penaeid shrimp catch by $39.5 \%$ and total fish catch by $33.6 \%$. But marginal increase in $\mathrm{CPH}$ of penaeid shrimps and marginal decrease in $\mathrm{CPH}$ of total fish catch from span-1 to span-2, indicate that the exploitation has reached maximum sustainable level.

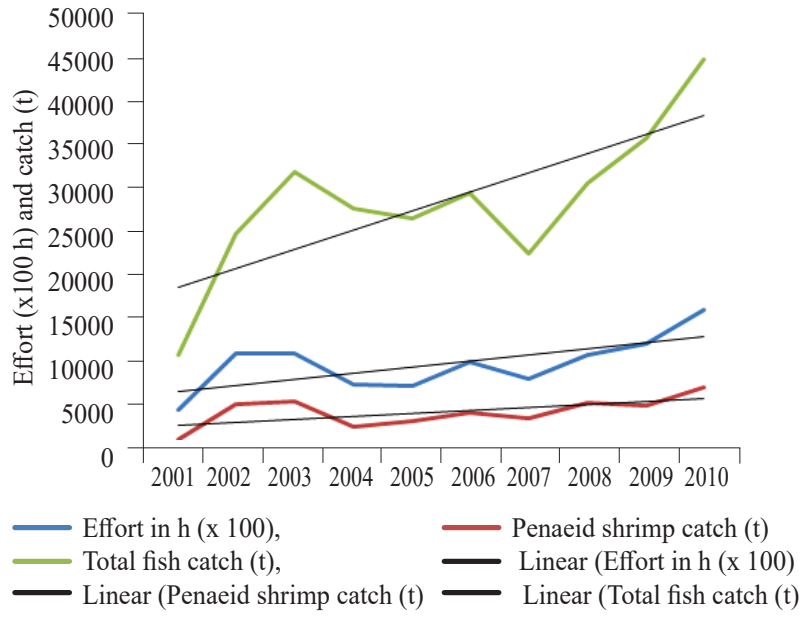

Fig. 1. Trends in effort, penaeid shrimp catch and total fish catch by sona boats

Month-wise $\mathrm{CPH}$ of penaeid shrimps and penaeid shrimp contribution in percentage to total fish landings during 2001-2010 are depicted in Fig. 2. It is observed that there is a spurt in $\mathrm{CPH}$ and percentage of penaeid shrimp catch in June, immediately after fishing ban which is observed for 45 days during April and May. June to October is the productive period in terms of $\mathrm{CPH}$ and percentage of penaeid shrimps to total fish landings.

Mean month-wise species composition of penaeid shrimps by weight during span-1 (2001-2005) is presented in Table 2. Commercial species such as Metapenaeus monoceros, Penaeus indicus, Penaeus monodon and Penaeus semisulcatus contributed throughout the year which accounted for about $20 \%$ of total annual penaeid shrimp landings. Metapenaeus dobsoni, though occupied third position in terms of contribution, the catch was significant during June to October compared to the remaining months when the catch recorded was low. About $42 \%$ of penaeid shrimp landings per year on an average were landed in the form of dry shrimps. Small size shrimps such as Metapenaeopsis spp., Solenocera spp., Parapenaeopsis spp., Trachypenaeus spp. and Parapenaeus sp. were the major components of dry shrimps (Das et al., 2013). During the initial period of cruise, all commercial species of penaeid shrimps and other commercial fin fishes having high value are stored in ice and the remaining less value small size shrimps are sundried in the deck or on top of the boat. The small size shrimps that are caught during last 2-3 days of the cruise $(28.2 \%)$ are brought to the fishing harbour in fresh condition stored in ice, depending upon the availability of storage facility. In total, contribution of commercial species is $19.7 \%, M$. dobsoni formed $9.9 \%$, smaller shrimps in fresh condition $28.2 \%$ and dried smaller shrimps contributed 42\%. On an average, during 2001-2005, 

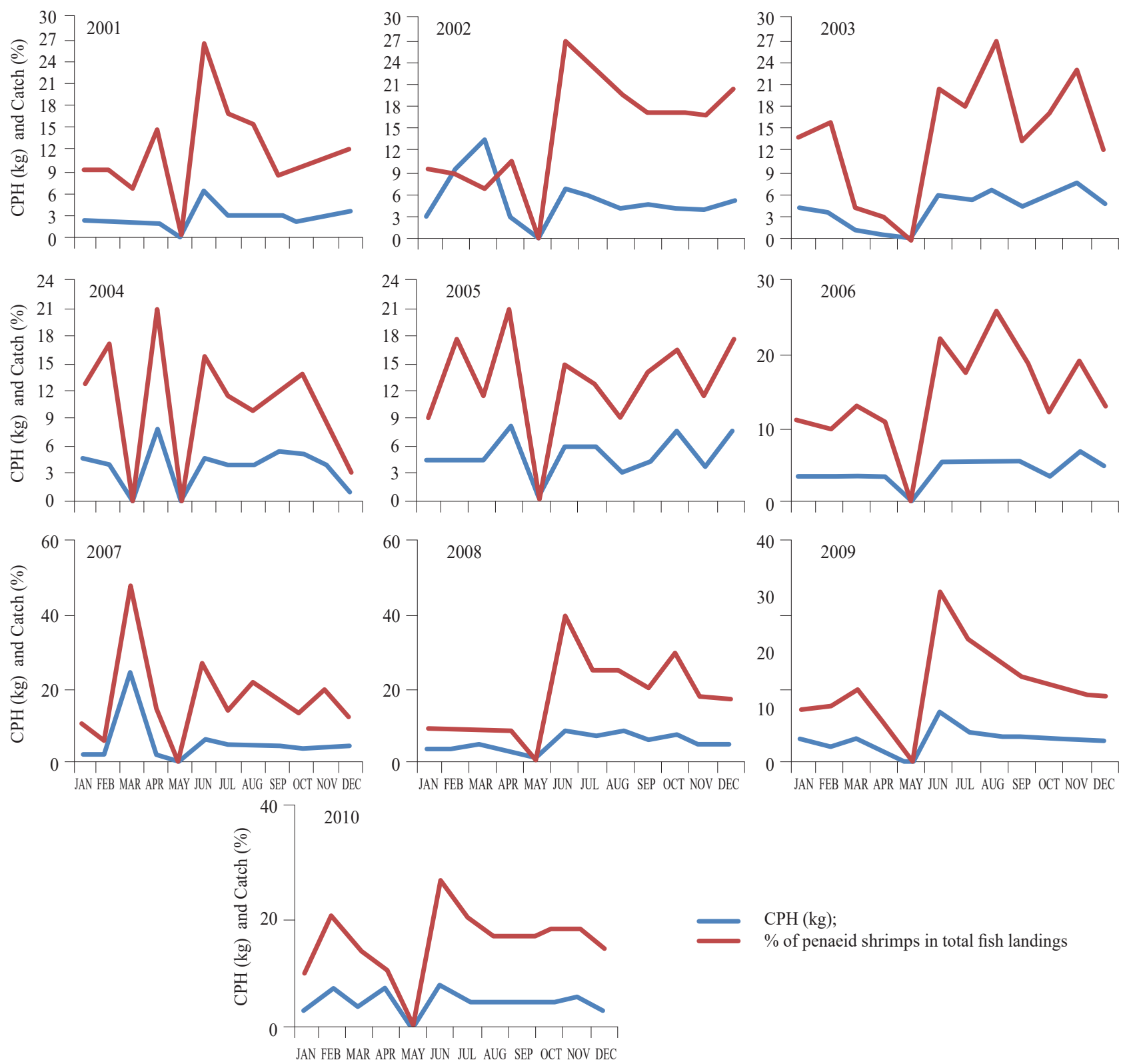

Fig. 2. Month-wise $\mathrm{CPH}(\mathrm{kg})$ and $\%$ of penaeid shrimps in total fish landings from sona boats based at Visakhapatnam Fishing Harbour during 2001-2010

M. monoceros (12.5\%) dominated the shrimp catch, followed by Metapenaeopsis spp. (10.1\%), M. dobsoni (9.9\%), Parapenaeopsis spp. (7.1\%), Solenocera spp. (6.2\%), P. indicus (4.7\%), Trachypenaeus spp. (2.6\%), P. monodon $(1.7 \%)$ and P. semisulcatus $(0.8 \%)$.

Mean month-wise species composition by weight during span-2 (2006-2010) is given in Table 3. Commercial species like $M$. monoceros, $M$. affinis, P. indicus, P. monodon, P. semisulcatus and P. japonicus contributed throughout the year and their share was about 50\%. M. dobsoni and M. brevicornis formed $14.5 \%$. Smaller shrimps such as Metapenaeopsis spp.,
Solenocera spp., Parapenaeopsis spp., Trachypenaeus spp., Parapenaeus sp. and others recorded $34.5 \%$. Share of dried smaller shrimps was low (1\%). On an average during 2006-2010 M. monoceros dominated (33.8\%), followed by Solenocera spp. (17.4\%), M. dobsoni (13.2\%), Metapenaeopsis spp. (8.7\%), P. indicus (5.7\%), Parapenaeopsis spp. (5.7\%), P. monodon (3.9\%), M. affinis (3.7\%), P. semisulcatus (1.7\%) and Trachypenaeus spp. $(1.3 \%)$.

M. monoceros dominated the shrimp catch landed by sona boats during both spans (2001-2010). Maheswarudu et al. (2014) reported species composition of penaeid 
Table 2. Mean month-wise species composition (by weight) of penaeid shrimp landings from sona boats based at Visakhapatnam Fishing Harbour during 2001-2005 (span-I)

\begin{tabular}{|c|c|c|c|c|c|c|c|c|c|c|c|c|c|c|}
\hline & Jan & Feb & Mar & Apr & May & Jun & Jul & Aug & Sep & Oct & Nov & Dec & Total & \\
\hline Effort (units) & 384 & 636 & 683 & 315 & & 411 & 780 & 822 & 587 & 581 & 743 & 484 & 6426 & \\
\hline Effort (h) & 42338 & 84030 & 72798 & 35291 & 0 & 53277 & 120195 & 126160 & 75146 & 79496 & 102608 & 63638 & 854977 & \\
\hline Total fish catch (t) & 1168 & 1779 & 2322 & 1122 & 0 & 1560 & 3357 & 3266 & 2348 & 2393 & 3297 & 2113 & 24724 & \\
\hline Penaeid catch (t) & 156 & 304 & 257 & 185 & & 308 & 539 & 586 & 338 & 378 & 507 & 281 & 3841 & \\
\hline Contribution of penaeids to total fish catch (\%) & 13.4 & 17.1 & 11.1 & 16.5 & 0 & 19.8 & 16.0 & 17.9 & 14.4 & 15.8 & 15.4 & 13.3 & 15.5 & \\
\hline $\mathrm{CPH}$ of penaeids $(\mathrm{kg})$ & 3.7 & 3.6 & 3.5 & 5.3 & 0 & 5.8 & 4.5 & 4.6 & 4.5 & 4.8 & 4.9 & 4.4 & 4.5 & \\
\hline Species composition by wt. (t) & & & & & & & & & & & & & & $\%$ \\
\hline M. monoceros & 17.81 & 22.24 & 23.85 & 18.35 & 0 & 47.55 & 91.60 & 82.44 & 43.93 & 37.62 & 58.44 & 37.73 & 481.56 & 12.5 \\
\hline M. dobsoni & 2.47 & 3.53 & 7.13 & 1.05 & 0 & 133.1 & 96.96 & 65.65 & 38.39 & 22.10 & 7.74 & 1.14 & 379.23 & 9.9 \\
\hline M. brevicornis & 0.00 & 0.00 & 0.00 & 0.00 & 0 & 0 & 0.00 & 0.00 & 0.00 & 0.00 & 0.00 & 0.00 & 0.00 & 0.0 \\
\hline M. affinis & 0.00 & 0.00 & 0.00 & 0.00 & 0 & 0 & 0.00 & 0.00 & 0.00 & 0.00 & 0.00 & 0.00 & 0.00 & 0.0 \\
\hline Metapenaeopsis spp. & 20.83 & 35.36 & 32.52 & 48.76 & 0 & 14.21 & 37.00 & 49.00 & 34.71 & 40.10 & 47.45 & 28.26 & 388.19 & 10.1 \\
\hline P. indicus & 3.80 & 8.99 & 7.73 & 3.65 & 0 & 29.44 & 43.80 & 26.15 & 21.50 & 11.34 & 18.29 & 5.31 & 179.99 & 4.7 \\
\hline P. monodon & 3.07 & 4.19 & 3.69 & 1.90 & 0 & 3.626 & 10.45 & 7.33 & 5.81 & 7.35 & 13.51 & 4.72 & 65.65 & 1.7 \\
\hline P. merguiensis & 0.00 & 0.00 & 0.00 & 0.00 & 0 & 0 & 0.00 & 0.00 & 0.00 & 0.00 & 0.00 & 0.00 & 0.00 & 0.0 \\
\hline P. japonicus & 0.00 & 0.00 & 0.00 & 0.00 & 0 & 0 & 0.00 & 0.00 & 0.00 & 0.00 & 0.00 & 0.00 & 0.00 & 0.0 \\
\hline P. semisulcatus & 1.25 & 1.20 & 2.47 & 0.92 & 0 & 2.352 & 5.94 & 3.98 & 3.08 & 3.91 & 3.69 & 2.66 & 31.44 & 0.8 \\
\hline Solenocera spp. & 19.60 & 21.66 & 18.97 & 4.25 & 0 & 4.685 & 27.43 & 25.83 & 35.61 & 27.01 & 27.66 & 27.35 & 240.04 & 6.2 \\
\hline Parapenaeopsis spp. & 6.75 & 20.78 & 17.05 & 11.91 & 0 & 14.65 & 22.59 & 22.04 & 26.27 & 56.79 & 61.91 & 13.37 & 274.09 & 7.1 \\
\hline Trachypenaeus spp. & 7.17 & 4.01 & 5.69 & 1.30 & 0 & 2.474 & 17.13 & 8.51 & 8.84 & 7.62 & 13.30 & 22.74 & 98.80 & 2.6 \\
\hline Parapenaeus sp. & 0.23 & 0.13 & 23.23 & 0.16 & 0 & 0.185 & 1.67 & 0.20 & 0.31 & 0.51 & 0.78 & 0.41 & 27.82 & 0.7 \\
\hline Other smaller shrimps & 15.60 & 0.64 & 24.00 & 0.51 & 0 & 1.107 & 2.55 & 1.54 & 2.67 & 3.49 & 3.14 & 4.07 & 59.30 & 1.5 \\
\hline Dry shrimps (converted into wet wt.) & 57.82 & 181.36 & 90.6 & 92.61 & 0 & 55.14 & 181.47 & 293.29 & 117.32 & 160.5 & 250.97 & 133.56 & 1614.69 & 42.0 \\
\hline Total penaeids & 156.38 & 304.09 & 256.9 & 185.36 & 0 & 308.5 & 538.59 & 585.96 & 338.43 & 378.4 & 506.86 & 281.32 & 3840.81 & 100.0 \\
\hline
\end{tabular}

Table 3. Month-wise species composition by weight of penaeid shrimp landings from sona boats at Visakhapatnam Fishing Harbour during 2006-2010 (span-2)

\begin{tabular}{|c|c|c|c|c|c|c|c|c|c|c|c|c|c|c|}
\hline & Jan & Feb & Mar & Apr & May & Jun & Jul & Aug & Sep & Oct & Nov & Dec & Total & \\
\hline Effort (units) & 722 & 605 & 676 & 530 & & 623 & 876 & 983 & 1012 & 919 & 855 & 922 & 8724 & \\
\hline Effort (h) & 100790 & 78800 & 79622 & 45704 & & 77125 & 117974 & 134696 & 147603 & 140171 & 112859 & 140142 & 1175485 & \\
\hline Total fish catch (t) & 3147 & 2499 & 2588 & 1415 & & 1937 & 3201 & 3358 & 3810 & 3654 & 3461 & 3953 & 33023 & \\
\hline Penaeid catch (t) & 311 & 283 & 367 & 153 & & 513 & 644 & 686 & 670 & 624 & 575 & 534 & 5360 & \\
\hline Contribution of penaeids to total fish catch (\%) & 9.9 & 11.3 & 14.2 & 10.8 & 0 & 26.5 & 20.1 & 20.4 & 17.6 & 17.1 & 16.6 & 13.5 & 16.2 & \\
\hline $\mathrm{CPH}$ of penaeids $(\mathrm{kg})$ & 3.1 & 3.6 & 4.6 & 3.3 & 0 & 6.7 & 5.5 & 5.1 & 4.5 & 4.5 & 5.1 & 3.8 & 4.6 & \\
\hline Species composition by wt. (t) & & & & & & & & & & & & & & $\%$ \\
\hline M. monoceros & 104.85 & 87.63 & 118.31 & 70.48 & 0 & 147.81 & 223.20 & 201.71 & 208.49 & 212.52 & 190.52 & 247.97 & 1813.48 & 33.8 \\
\hline M. dobsoni & 8.41 & 9.60 & 6.91 & 5.00 & 0 & 187.10 & 116.19 & 133.47 & 76.56 & 85.71 & 50.67 & 28.49 & 708.11 & 13.2 \\
\hline M. brevicornis & 0.01 & 0.35 & 0.43 & 0.00 & 0 & 8.27 & 5.12 & 14.14 & 6.00 & 8.14 & 26.90 & 1.70 & 71.05 & 1.3 \\
\hline M. affinis & 9.00 & 8.26 & 4.62 & 0.79 & 0 & 15.16 & 25.55 & 26.40 & 32.05 & 27.52 & 23.09 & 24.67 & 197.10 & 3.7 \\
\hline Metapenaeopsis spp. & 37.33 & 41.54 & 47.69 & 25.92 & 0 & 33.28 & 51.18 & 37.93 & 46.97 & 34.72 & 75.87 & 35.98 & 468.41 & 8.7 \\
\hline P. indicus & 14.03 & 7.86 & 10.27 & 3.48 & 0 & 26.62 & 42.97 & 50.32 & 47.57 & 41.13 & 31.99 & 28.22 & 304.46 & 5.7 \\
\hline P. monodon & 12.01 & 8.66 & 9.80 & 5.29 & 0 & 11.47 & 20.22 & 38.46 & 36.35 & 24.55 & 22.50 & 17.31 & 206.62 & 3.9 \\
\hline P. merguiensis & 0.01 & 0.00 & 0.03 & 0.00 & 0 & 0.00 & 1.26 & 1.88 & 4.30 & 0.89 & 0.59 & 0.06 & 9.01 & 0.2 \\
\hline P. japonicus & 1.39 & 0.95 & 2.00 & 1.36 & 0 & 3.96 & 6.36 & 6.60 & 4.62 & 12.35 & 7.30 & 4.93 & 51.81 & 1.0 \\
\hline P. semisulcatus & 4.37 & 3.59 & 5.31 & 3.31 & 0 & 6.29 & 9.09 & 9.96 & 16.48 & 9.11 & 12.48 & 10.92 & 90.92 & 1.7 \\
\hline Solenocera spp. & 74.07 & 78.51 & 125.25 & 23.07 & 0 & 38.84 & 91.26 & 95.29 & 112.43 & 90.68 & 100.59 & 103.81 & 933.80 & 17.4 \\
\hline Parapenaeopsis spp. & 9.15 & 8.34 & 5.49 & 4.04 & 0 & 21.97 & 38.71 & 52.69 & 59.68 & 63.55 & 24.41 & 16.93 & 304.95 & 5.7 \\
\hline Trachypenaeus spp. & 9.00 & 8.81 & 12.86 & 1.04 & 0 & 3.78 & 5.77 & 7.11 & 8.15 & 5.04 & 2.47 & 5.36 & 69.38 & 1.3 \\
\hline Parapenaeus sp. & 10.30 & 2.00 & 1.62 & 3.25 & 0 & 1.44 & 6.51 & 5.95 & 8.88 & 7.25 & 5.61 & 7.81 & 60.62 & 1.1 \\
\hline Other smaller shrimps & 1.82 & 3.58 & 0.81 & 1.55 & 0 & 4.36 & 0.31 & 4.47 & 1.05 & 0.70 & 0.29 & 0.00 & 18.95 & 0.4 \\
\hline Dry shrimps (converted into wet wt.) & 14.77 & 13.61 & 15.40 & 4.50 & 0 & 3.14 & 0.00 & 0.00 & 0.00 & 0.00 & 0.00 & 0.00 & 51.42 & 1.0 \\
\hline Total penaeids & 310.50 & 283.29 & 366.80 & 153.07 & 0 & 513.49 & 643.71 & 686.37 & 669.55 & 623.85 & 575.27 & 534.18 & 5360.08 & 100.0 \\
\hline
\end{tabular}


shrimps both for east coast of India and Andhra Pradesh, based on the data for the period 1991-2002, wherein M. dobsoni dominated followed by M. monoceros. The study took into account, the species composition of shrimps from Kakinada Fishing Harbour. The domination of $M$. monoceros observed in the present study, could be attributed to location specific species dominance.

The increase in contribution of commercial species from 19.7 to $50 \%$ and decrease of smaller shrimps in the dry form from 42 to $1 \%$ during span- 1 to span-2, indicate that targeted fishing for commercial species was carried out during span-2 to gain higher profit.

Month-wise comparison of catch and $\mathrm{CPH}$ of penaeid shrimps between two spans are given in Fig. 3. It is apparent that penaeid shrimp catch increased in all the months during span-2 and CPH remained without change between two spans. Species-wise comparison of mean annual catch, CPH and percentage contribution, between two spans is given in Table 4. Catch of nine genera/species (M. monoceros, M. dobsoni, Metapenaeopsis spp., P. indicus, P. monodon, P. semisulcatus, Solenocera spp., Parapenaeopsis spp. and Parapenaeus sp.) has increased whereas catch of Trachypenaeus spp., other small shrimps and dry shrimps decreased from span-1 to span-2. Catch of Metapenaeus brevicornis, M. affinis, Penaeus merguiensis and Penaeus japonicus were recorded only during second span. During span-1, due to misidentification, M. brevicornis catch was merged with M. dobsoni;

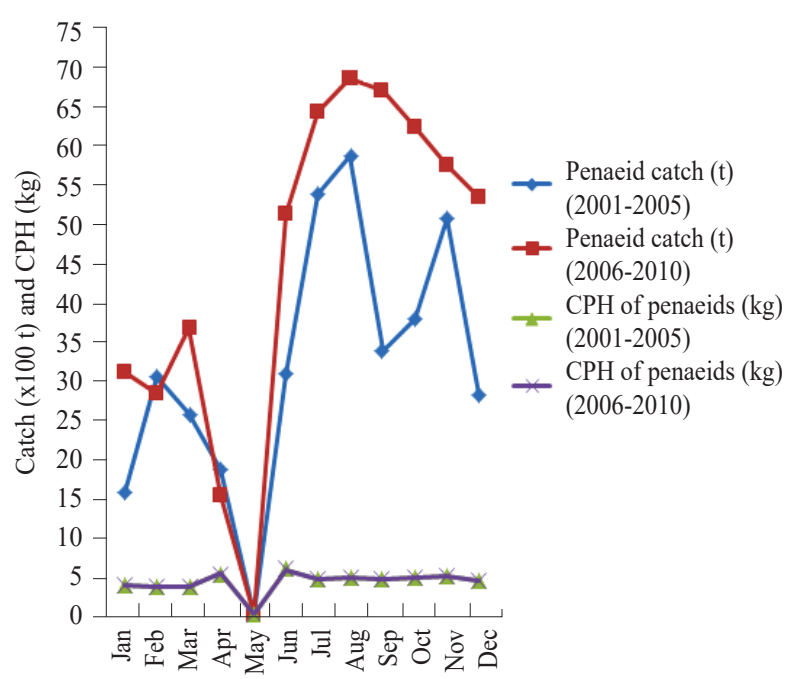

Fig. 3. Monthwise comparison of catch and $\mathrm{CPH}$ of penaeid shrimps between two spans

M. affinis with $M$. monoceros; P. merguiensis with $P$. indicus and P. japonicus with $P$. semisulcatus.

Catch per hour of 7 genera/species (M. monoceros, M. dobsoni, P. indicus, P. monodon, P. semisulcatus, Solenocera spp. and Parapenaeus sp.) increased whereas CPH of Metapenaeopsis spp., Parapenaeopsis spp., Trachypenaeus spp., other small shrimps and dry shrimps decreased from span-1 to span-2. This may be due to targeted fishing for commercial species. Though catch of Metapenaeopsis spp. and Parapenaeopsis spp. increased from span-1 to span-2, the decrease in $\mathrm{CPH}$ for these two

Table 4. Species-wise comparison of mean annual catch, species composition and CPH between two spans

\begin{tabular}{|c|c|c|c|c|c|c|c|c|c|}
\hline \multirow[b]{2}{*}{ Species } & \multicolumn{3}{|c|}{ Catch $(t)$} & \multicolumn{3}{|c|}{$\mathrm{CPH}(\mathrm{kg})$} & \multicolumn{3}{|c|}{ Species composition $(\%)$} \\
\hline & $2001-2005$ & 2006-2010 & $\begin{array}{l}\text { Increase/ } \\
\text { decrease } \\
(\%)\end{array}$ & 2001-2005 & 2006-2010 & $\begin{array}{l}\text { Increase/ } \\
\text { decrease } \\
(\%)\end{array}$ & $2001-2005$ & 2006-2010 & $\begin{array}{l}\text { Increase/ } \\
\text { decrease } \\
(\%)\end{array}$ \\
\hline M. monoceros & 481.56 & 1813.48 & 276.6 & 0.563 & 1.543 & 173.9 & 12.5 & 33.8 & 169.8 \\
\hline M. dobsoni & 379.23 & 708.11 & 86.7 & 0.444 & 0.602 & 35.8 & 9.9 & 13.2 & 33.8 \\
\hline M. brevicornis & 0.00 & 71.05 & 0.0 & 0.000 & 0.060 & 0.0 & 0.0 & 1.3 & 0.0 \\
\hline M. affinis & 0.00 & 197.10 & 0.0 & 0.000 & 0.168 & 0.0 & 0.0 & 3.7 & 0.0 \\
\hline Metapenaeopsis spp. & 388.19 & 468.41 & 20.7 & 0.454 & 0.398 & -12.2 & 10.1 & 8.7 & -13.5 \\
\hline P. indicus & 179.99 & 304.46 & 69.2 & 0.211 & 0.259 & 23.0 & 4.7 & 5.7 & 21.2 \\
\hline P. monodon & 65.65 & 206.62 & 214.7 & 0.077 & 0.176 & 128.9 & 1.7 & 3.9 & 125.5 \\
\hline P. merguiensis & 0.00 & 9.01 & 0.0 & 0.000 & 0.008 & 0.0 & 0.0 & 0.2 & 0.0 \\
\hline P. japonicus & 0.00 & 51.81 & 0.0 & 0.000 & 0.044 & 0.0 & 0.0 & 1.0 & 0.0 \\
\hline P. semisulcatus & 31.44 & 90.92 & 189.2 & 0.037 & 0.077 & 110.3 & 0.8 & 1.7 & 107.2 \\
\hline Solenocera spp. & 240.04 & 933.80 & 289.0 & 0.281 & 0.794 & 182.9 & 6.2 & 17.4 & 178.8 \\
\hline Parapenaeopsis spp. & 274.09 & 304.95 & 11.3 & 0.321 & 0.259 & -19.1 & 7.1 & 5.7 & -20.3 \\
\hline Trachypenaeus spp. & 98.80 & 69.38 & -29.8 & 0.116 & 0.059 & -48.9 & 2.6 & 1.3 & -49.7 \\
\hline Parapenaeus sp. & 27.82 & 60.62 & 117.9 & 0.033 & 0.052 & 58.5 & 0.7 & 1.1 & 56.1 \\
\hline Other small shrimps & 59.30 & 18.95 & -68.0 & 0.069 & 0.016 & -76.8 & 1.5 & 0.4 & -77.1 \\
\hline Dry shrimps (converted into wet wt.) & 1614.69 & 51.42 & -96.8 & 1.889 & 0.044 & -97.7 & 42.0 & 1.0 & -97.7 \\
\hline Total penaeids & 3840.81 & 5360.08 & 39.6 & 4.492 & 4.560 & 1.5 & 100.0 & 100.0 & \\
\hline
\end{tabular}




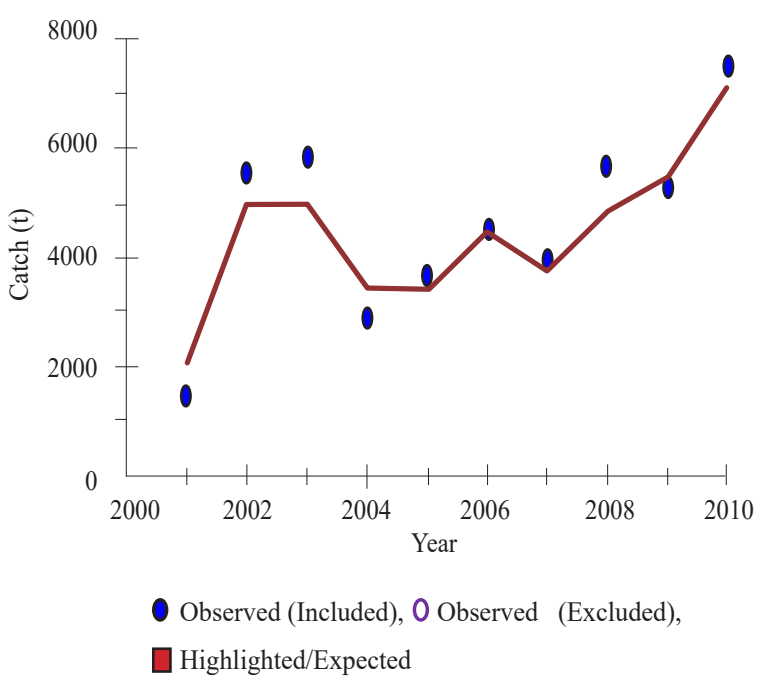

Fig. 4. Annual observed (0) and expected $(\rightarrow$ penaeid shrimp catch of sona boats based at Visakhapatnam Fishing harbour during 2001-2010

genera was due to non-proportional increase of catch with fishing effort.

Commercial species such as M. monoceros, M. affinis, P. monodon, P. indicus, P. merguiensis, P. semisulcatus and $P$. japonicas contributed $19.7 \%(757 \mathrm{t})$ of penaeid shrimp catch during span-1, their contribution during span-2 being $46.3 \%(2,482 \mathrm{t})$, resulting in three fold increase. M. dobsoni and M. brevicornis formed 9.9\% (379.2 t) during span-1 and 14.5\% (779.2 t) during span-2, which accounted for two fold increase. Solenocera spp. and Parapenaeus sp. contributed 6.9\% (267.8 t) during span-1 and $17.4 \%$ (994.4 t) during span-2, resulting in 3.7 fold increase. The other smaller shrimps viz., Metapenaeopsis spp., Parapenaeopsis spp., Trachypenaeus spp., and dry shrimps showed drastic reduction from $63.3 \%(2,498.4 \mathrm{t})$ during span-1 to $17.1 \%$ (913 t) during span-2. Three fold increase in catch of commercial species; two fold increase of M. dobsoni and M. brevicornis; and drastic reduction in the catch of smaller shrimps and dried shrimps during span-2, indicate targeted fishing for high value commercial species during the period. Increase in cost of fishing operations such as diesel price and wages for labour, diverted the exploitation towards high value species during span-2. Availability of mobile phones with boat operators also resulted in successful targeted fishing as this aided in faster exchange of information between boat operators on availability of commercial species in specific fishing grounds.

Results based on analysis using Schaefer production model, for the ten years period (2001-2010) are depicted in Fig. 4 and 5. Exploitation of penaeid shrimps by sona

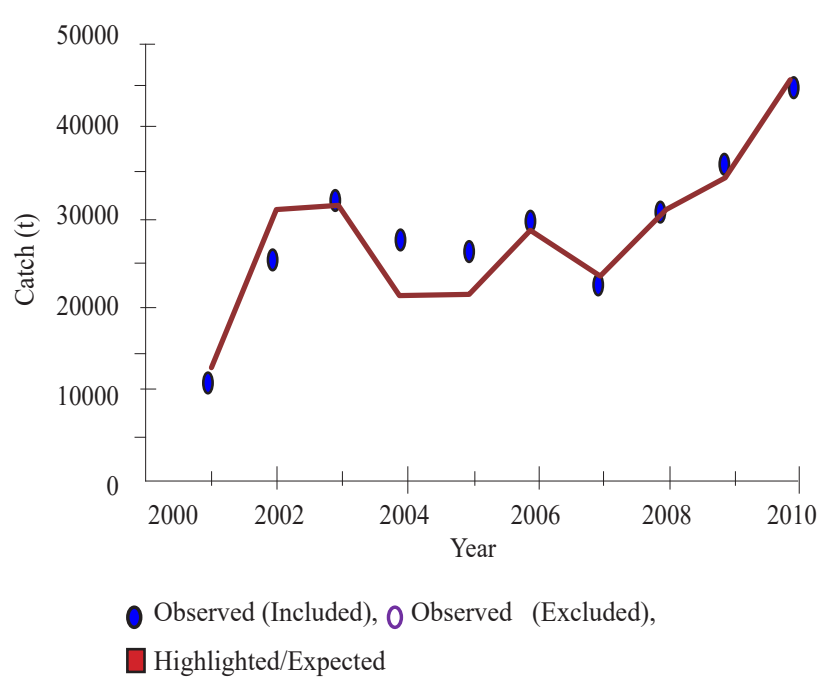

Fig. 5. Annual observed ( $\square$ and expected (-) total fish catch of Sona boats based at Visakhapatnam Fishing Harbour during 2001-2010

boats was at above expected level during four years (2002, 2003, 2008 and 2010), below expected level during two years (2001 and 2004) and at optimum level during 2005, 2006, 2007 and 2009 (Fig. 4). Fig. 5 indicates that exploitation of total fish resource was at above expected level during 2004 and 2005, below expected level during two years (2001 and 2002) and at optimum level during 2003, 2006, 2007, 2008, 2009 and 2010. Considering the exploitation status of both penaeid shrimps and total fish resources, it is advisable to restrict fishing effort at the 2009-2010 to ensure their sustainability.

\section{Acknowledgements}

The authors express their gratitude to the Director, ICAR-Central Marine Fisheries Research Institute, Kochi, Kerala, India.

\section{References}

Borisow, N. I. 1962. Report to the Government of India on experimental and exploratory fishing in the Bay of Bengal. Report No.7466, FAO, Rome, p. I-29.

Chittibabu, K., Ramalingam, P., Dhanaraju, K. and Nageswara Rao, T. 1988. Introduction of 43 footer mechanised boats for commercial trawling along the coast of Andhra Pradesh. Mar. Fish. Infor. Serv.; T\&E Ser., 86: 27-29.

Das Madhumita, Rohit Prathibha, Maheswarudu, G., Dash Biswajit and Ramana, P. V. 2013. Overview of dry fish landings and trade at Visakhapatnam Fishing Harbour. Mar. Fish. Infor. Serv.; T\&E Ser., 215: 3-7.

Kirkwood, G. P., Aukland, R. and Zara, S. J. 2001. Catch effort data analysis (CEDA), Version 3.0. MARG Ltd., London, UK. 
Kutty, M. K., Kesavan, A. K. and Qasim, S. Z. 1973. An evaluation of the sampling design adopted by Central Marine Fisheries Research Institute for estimating marine fish production of India. Indian J. Fish., 20(1): 16-34.

Maheswarudu, G., Rao, G. Sudhakara, Rajamani, M., Thangaraj Subramanian, V., Nair K. R. Manmadhan, Saleela, K. N., Dhanwanthari, E. Sreeram, Miriam Paul and Unnithan, A. K. 2014. Penaeid prawn resources along the east coast of India during 1991-2011. Mar. Fish. Infor. Serv. T\&E Ser., 219: 8-14.

Maheswarudu, G., Sreeram, Miriam Paul, Dhanwanthari, E., Varma, J. B., Sajeev, C. K. and Satyarao, S. 2015. Exploitation of penaeid shrimp resources by small mechanised trawlers off Visakhapatnam, Andhra Pradesh. Indian J. Fish., 62(2): 7-13.

Naumov, K. V. 1961. A survey of the fisheries resources of the Bay of Bengal. Report No. 1393. FAO, Rome, p. I - 60.
Poliakov, M. P. 1961. Interim Report to the Govt. of India on experimental and exploratory trawling in the Bay of Bengal in 1960 - 61. FAO (Mimeo), p. 1-23.

Poliakov, M. P. 1962. Report to the Government of India on exploratory trawling in the Bay of Bengal. FAO EPTA Report No. 1573.

Rajkumar, U., Maheswarudu, G., Nasser, A. K. V., Rao, K. N., Kingsley, H. J., Varma, J. B. and Rao, M. P. 2004. Trawl fisheries off Visakhapatnam. In: Boopendranath, M. R., Mathew, P. T., Gupta, S. S., Pravin, P. and Jeeva, J. E. (Eds.), Sustainable fisheries development: Focus on Andhra Pradesh, Society of Fisheries Technologists (India), Cochin, p. 35-49.

Rao, G. Sudhakara. 1999. Prawn fishery by the sona boats at Visakhapatnam. Indian J. Fish., 46(1): 13-23. 